\title{
Layanan Reservasi Online di Orchid Forest
}

\author{
M D Rahmatya ${ }^{1}$, M F Wicaksono ${ }^{2}$, M N Mubarok ${ }^{3}$ \\ Program Studi Manajemen Informatika, Universitas Komputer Indonesia ${ }^{1}$ \\ Program Studi Teknik Komputer, Universitas Komputer Indonesia ${ }^{2}$ \\ Program Studi Sistem Informasi, Universitas Komputer Indonesia ${ }^{3}$ \\ Jl. Dipatiukur No. 112-116, Bandung, 40132, Indonesia ${ }^{123}$ \\ myrna@email.unikom.ac.id*1 \\ diterima: 11 Februari 2020 \\ direvisi: 18 Februari 2020 \\ dipublikasi: 3 Maret 2020
}

\begin{abstract}
Abstrak
Orchid Forest adalah salah satu wisata edukasi yang berlokasi di Cikole, Indonesia. Orchid Forest sering digunakan sebagai lokasi acara. Namun, tidak banyak informasi tentang Hutan Anggrek tersedia di internet. Promosi dan informasi terbatas pada feed Instagram Orchid Forest. Untuk dapat memperoleh informasi lebih lanjut, pelanggan harus menghubungi atau mengunjungi Orchid Forest. Sebagian besar pelanggan Orchid Forest berasal dari luar kota. Kebanyakan dari mereka mengetahui Orchid Forest dari mulut ke mulut. Orchid Forest tidak memiliki media lain untuk memperluas jangkauan promosinya, di mana pelanggan dapat memperoleh informasi yang memadai tentang prosedur dan biaya menyewa lokasi acara di Orchid Forest. Oleh karena itu, perlu untuk merancang situs web yang dapat menyajikan informasi yang memadai tentang Orchid Forest. Metode pendekatan sistem yang digunakan untuk menganalisis sistem adalah pendekatan berorientasi objek dan metode pengembangan sistem yang digunakan adalah waterfall. Desain sistem informasi reservasi adalah tujuan dari penelitian ini. Sistem ini dirancang tidak hanya sebagai media promosi tetapi juga sebagai sistem informasi yang memungkinkan pelanggan melakukan reservasi untuk lokasi acara dan pembayaran melalui situs web.
\end{abstract}

Kata kunci: Sistem Informasi; Reservasi; Reservasi online

\begin{abstract}
Orchid Forest is one of the educational tours located in Cikole, Indonesia. Orchid Forest is often used as the location of events. However, not much information about Orchid Forest is available on the internet. Promotion and information are limited to the Orchid Forest's Instagram feed. To be able to get more information, the customers must contact or visit the Orchid Forest. Most of the customers of Orchid Forest come from out of town. Mostly they know Orchid Forest by word of mouth. Orchid Forest does not have any other media to expand the reach of its promotions, where customers can get adequate information about the procedures and costs of renting event locations in Orchid Forest. Therefore, it is necessary to design a website that can present adequate information about Orchid Forest. The system approach method used to analyze the system is an objectoriented approach and the system development method used is the waterfall. The design of the reservation information system is the aim of this study. The system was designed not only as a promotional medium but also as an information system that allows customers to make a reservation for event locations and payments through the website.
\end{abstract}

Keywords: Information System; Reservation; Online Reservation 


\section{Pendahuluan}

Reservasi adalah proses, pembuatan, pemesanan (tempat, barang, dan sebagainya) kepada orang lain. Di era modern ini, pemesanan tempat untuk berbagai acara sudah tidak asing lagi. Apalagi dengan semakin banyak lokasi menarik yang bisa dijadikan lokasi acara khusus. Secara umum, lokasi yang relatif menarik ini jauh dari daerah perkotaan. Lokasi yang jauh dari perkotaan sering diminati oleh banyak orang karena memiliki pemandangan yang indah. Namun, di balik banyaknya lokasi acara yang menarik, informasi yang tersedia masih minim. Beberapa telah menggunakan media sosial sebagai media promosi. Namun tetap saja, informasi yang dapat diperoleh melalui akun media sosial tidak lengkap. Demikian juga bagi pelanggan yang ingin melakukan reservasi harus mengunjungi lokasi untuk mendapatkan informasi lengkap dan membuat perjanjian reservasi. Sementara itu, sistem komputerisasi lebih efisien, terutama kita hidup di era informasi [1]. Inilah sebabnya mengapa sistem reservasi acara yang baik diperlukan untuk membuat tugas ini lebih mudah [2]. Sistem reservasi online memudahkan pelanggan untuk dapat membuat reservasi dan mendapatkan informasi yang memadai kapan saja dan di mana saja melalui internet [3] [4] [5].

Banyak lokasi wisata memiliki panorama yang indah dan suasana yang menenangkan. Banyak dari mereka dijadikan lokasi acara. Orchid Forest adalah salah satu wisata edukasi yang berlokasi di Cikole, Indonesia. Orchid Forest sering digunakan sebagai lokasi acara. Berdasarkan pengamatan penulis, tidak banyak informasi tentang Orchid Forest yang tersedia di internet. Promosi dan informasi terbatas pada feed Instagram Orchid Forest. Tentunya pelanggan tidak mendapatkan informasi yang cukup dan memadai. Untuk dapat memperoleh informasi lebih lanjut, pelanggan harus menghubungi atau mengunjungi Orchid Forest. Sebagian besar pelanggan datang dari luar kota. Orchid Forest belum memiliki media untuk memperluas jangkauan promosinya, di mana pelanggan dapat memperoleh informasi yang memadai tentang prosedur dan biaya menyewa lokasi acara. Dalam hal ini, media yang dimaksud adalah web resmi Orchid Forest.

Oleh karena itu, perlu untuk merancang situs web yang dapat menyajikan informasi yang memadai tentang Orchid Forest. Dengan merancang sistem informasi ini, keuntungan dari sistem reservasi seperti hemat waktu, layanan 24 jam, akses ke informasi dari mana saja, penawaran yang dipersonalisasi kepada pelanggan mereka dan banyak lagi yang akan dicapai [6]. Studi lain yang dilakukan di Indonesia (2018) menyimpulkan bahwa sistem informasi dapat meningkatkan kualitas pemrosesan data sehingga penyampaian informasi dapat diterima dengan mudah dan cepat [7]. Penelitian yang dilakukan pada tahun 2011 tentang pemesanan kamar hotel, merancang sistem informasi yang dapat membantu manajer front office, terutama dalam mengalokasikan dan memesan kamar, serta mengambil keputusan yang tepat [1]. Penelitian yang membahas tentang Analisis dan Desain Sistem Manajemen Reservasi Ruang Pelatihan Berdasarkan Kerangka SSH, telah mengubah ruang pelatihan dari booking management berbasis kertas menjadi booking management online dan membangun platform interaktif baik antara guru dan manajemen ruang pelatihan [8]. Kedua studi memiliki topik reservasi. Namun, keduanya tidak membahas reservasi dan pembayaran. Oleh karena itu, penelitian ini bertujuan untuk membuat media promosi Orchid Forest yang juga berfungsi sebagai media bagi pelanggan untuk melakukan reservasi dan pembayaran.

\section{Kajian Pustaka}

Sistem informasi adalah sekumpulan komponen-komponen yang saling terhubung dan saling bekerja sama satu sama lain untuk mencapai suatu tujuan, yaitu mengolah data menjadi informasi yang akurat [9]. Dalam sistem informasi terdapat enam blok, yaitu blok 
masukan, blok model, blok keluaran, blok teknologi, blok, basis data, dan blok kendali. Sistem informasi memiliki lima sumber daya diantaranya sumber daya manusia, sumber daya hardware, sumber daya software, data, dan jaringan [10]. Dewasa ini telah banyak yang memanfaatkan penggunaan sistem informasi untuk membantu dan mempermudah pekerjaan manusia salah satunya dalam hal reservasi online. Orchid Forest merupakan lokasi wisata yang telah banyak digunakan sebagai lokasi acara spesial untuk pertunjukkan, hiburan ataupun perayaan (event). Event dibedakan menjadi dua jenis, yaitu public event dan private event. Yang termasuk dalam public event diantaranya perayaan budaya, seni atau hiburan, bisnis atau perdagangan, kompetisi olah raga, pendidikan dan ilmu pengetahuan, rekreasi, serta politik atau kenegaraan. Private event meliputi perayaan pribadi seperti peringatan hari jadi, liburan keluarga, pesta pernikahan, dan pesta ulang tahun, serta social event seperti pesta-pesta, gala, dan acara reuni [11].

Kebanyakan pelanggan yang melakukan reservasi event di Orchid Forest berasal dari luar kota. Berdasarkan pengataman penulis, tidak banyak informasi yang tersedia mengenai Orchid Forest. Orchid Forest memiliki akun media sosial Instagram. Namun, akun media sosial seperti Instagram tidak dapat memberikan informasi yang lengkap dan memadai sesuai kebutuhan pelanggan. Untuk mendapatkan informasi lebih lengkap, pelanggan harus menghubungi pihak Orchid Forest atau datang langsung ke lokasi. Sementara itu, dengan membangun sebuah website dapat dijadikan sebagai media promosi untuk mengkomunikasikan produk dan layanan yang terdapat di Orchid Forest. Keutaman website sebagai media promosi, yaitu dapat diakses oleh masyakarat sehingga Orhid Forest dapat dikenal oleh masyarakat luas. Website Orchid Forest juga dapat digunakan untuk melakukan reservasi event secara online hingga pembayaran yang dikonfirmasi melalui website.

\section{Metode Penelitian}

Metode pendekatan sistem yang digunakan dalam menganalisis sistem yang berjalan dan dalam merancang sistem yang diusulkan, yaitu metode pendekatan berbasis objek. Sementara metode pengembangan sistem yang digunakan dalam menganalisis dan merancang layanan reservasi online di Orchid Forest adalah waterfall model.

Waterfall model adalah siklus hidup pengembangan perangkat lunak yang bersifat sekuensial linier. Model ini dinamai waterfall karena representasi diagramnya terlihat seperti aliran air. Selain itu, dikenal juga sebagai model siklus hidup klasik yang memiliki lima tahap yang merupakan requirements, the design of system and implementation, verification, dan maintenance (Gambar 1). Kontrol dipertahankan selama proyek melalui dokumentasi tertulis yang luas, tinjauan formal, dan persetujuan oleh user dan teknologi informasi terjadi pada akhir sebagian besar fase sebelum memulai fase berikutnya [12].

Pada tahapan requirements proses yang dilakukan adalah mengumpulkan data terkait reservasi event di Orchid Forest melalui observasi dan wawancara. Dokumen-dokumen yang dibutuhkan antara lain laporan reservasi event, laporan pembayaran reservasi event, daftar paket event, daftar fasilitas, data jadwal event, dan kwitansi pembayaran reservasi baik DP maupun kwitansi lunas.

Desain sistem akan digambarkan menggunakan UML. UML digunakan untuk mendukung pemodelan dan pengembangan sistem [13]. Sistem yang dirancang diilustrasikan melalui use case dan activity diagram. 


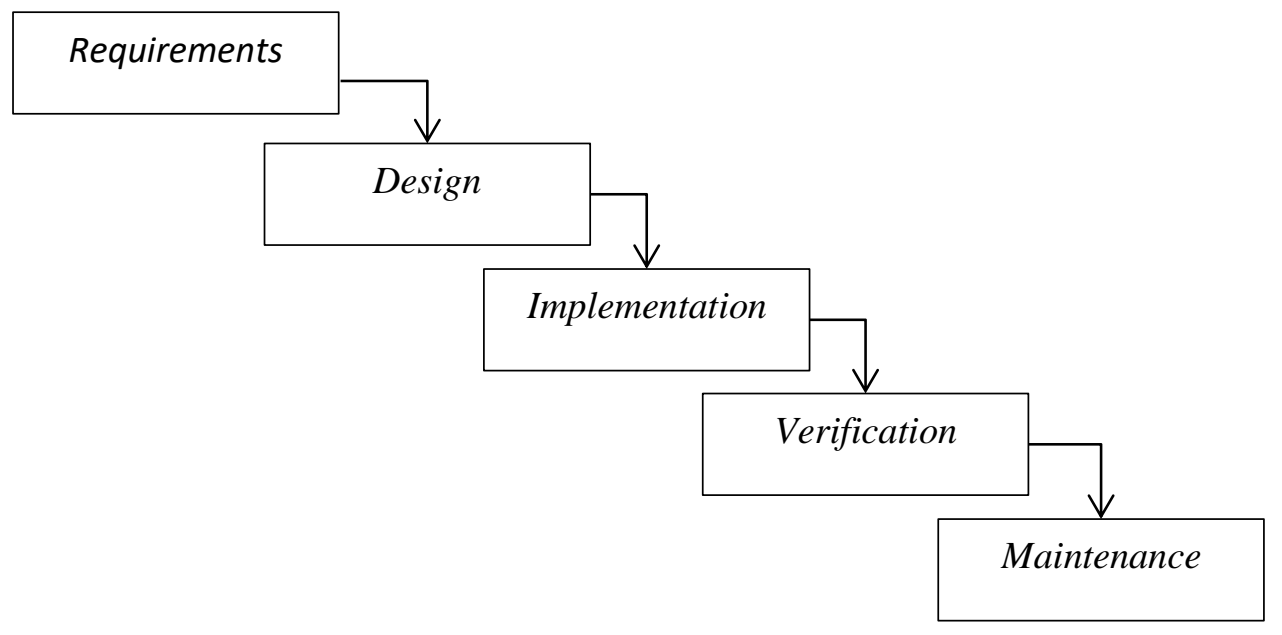

Gambar 1. Waterfall Model

Pada proses design mulai merancang sistem yang diusulkan mengenai reservasi event di Orchid Forest. Proses ini dimulai dari menggambarkan rancangan usecase, activity diagram, sequance diagram, dan class diagram. Dilanjutkan dengan merancang interface layanan reservasi online di Orchid Forest.

\section{Hasil dan Pembahasan}

Sistem yang berjalan di Orchid Forest dianalisis terlebih dahulu kemudian melakukan evaluasi terhadap sistem yang berjalan dan merancang sistem yang diusulkan. Hal ini dilakukan didasari dengan desain dalam perancangan sistem.

\subsection{Analisis Sistem yang Berjalan}

Hasil penelitian ini dapat membantu memperkenalkan Orchid Forest pada semua komunitas Indonesia dan dunia, dan memberikan informasi yang memadai melalui website. Selain itu, sistem yang dirancang akan memudahkan pelanggan untuk melakukan reservasi dan pembayaran. Penelitian serupa telah dilakukan berfokus pada sistem yang dapat membantu dalam mengelola pemesanan kamar dan booking ruangn pelatihan[1][8]. Namun, penelitian sebelumnya tidak fokus pada mengelola reservasi dan pembayarannya.

Sistem reservasi yang berjalan saat ini di Orchid Forest dimulai dengan pelanggan datang ke lokasi atau melalui telepon. Pelanggan yang berada di luar kota juga kesulitan mendapatkan informasi terkait promo di Orchid Forest. Kemudian proses pencatatan pembayaran dilakukan dengan mencatat pembayaran dalam sebuah buku. Penyimpanan data masih dalam bentuk arsip dokumen sehingga sulit untuk mencari data saat dibutuhkan dan membutuhkan waktu yang relatif lama dalam pemrosesan dan pelaporan data.

Promosi yang dilakukan Orchid Forest terbatas pada postingan di akun sosial media Instagram dan dari mulut ke mulut. Orchid Forest belum memiliki website resmi yang menyediakan informasi lengkap mengenai promo yang terdapat di Orchid Forest, layanan reservasi online, dan fasilitas yang dimiliki Orchid Forest.

Adapun detail alur reservasi, yaitu: pelanggan menghubungi operational staff melalui telepon atau dating langsung ke Orchid Forest untuk mendapatkan informasi mengenai reservasi atau melakukan reservasi. Operational staff memberikan informasi mengenai reservasi serta berdiskusi dengan pelanggan event apa yang akan dibuat. Operational staff memberikan form pelangganan. Pelanggan memberi form reservasi yang sudah terisi ke operational staff. Kemudian operational staff mengecek form reservasi yang telah diisi 
oleh pelanggan. Jika sudah sesuai maka berlanjut ke quotation dan jika tidak sesuai form reservasi dikembalikan dan dilengkapi oleh pelanggan. Quotation penawaran akan keluar setelah operational staff mengkaji kebutuhan yang tercantum dalam form serta quotation penawaran dikirim kepada pelanggan melalui email. Ketika pelanggan sudah merasa sesuai dengan harga yang ditawarkan, pelanggan mengkonfirmasi kembali kepada Operational staff, baik melalui telepon atau datang ke Orchid Forest. Apabila pelanggan merasa tidak cocok dengan harga yang ditawarkan, pelanggan dapat melakukan konfirmasi pembatalan reservasi. Apabila kedua belah pihak telah setuju dengan penawarannya, maka operational staff akan memberikan invoice. Jika Invoice sudah diterima, maka pelanggan melanjutkan ke proses pembayaran.

Pembayaran yang dilakukan pelanggan dapat dilunasi atau pembayaran uang muka. Kedua pembayaran tersebut dapat melalui transfer bank atau tunai di kantor Orchid Forest. Prosedur yang ada kemudian dianalisis dan dievaluasi untuk dapat mengetahui permasalahan, aktor, dan solusi seperti pada Tabel 1.

Tabel 1. Evaluasi sistem yang berjalan

\begin{tabular}{|c|c|c|c|}
\hline No & Permasalahan & Solusi & Aktor \\
\hline 1 & $\begin{array}{l}\text { Minimnya informasi mengenai } \\
\text { Orchid Forest karena belum } \\
\text { adanya website resmi yang } \\
\text { menyediakan informasi lengkap } \\
\text { mengenai Orchid Forest. } \\
\text { Sementara itu banyak pelanggan } \\
\text { Orchid Forest yang berasal dari } \\
\text { luar kota. Sistem yang berjalan } \\
\text { membuat pelanggan melakukan } \\
\text { reservasi langsung di Orchid } \\
\text { Forest atau melalui telepon. } \\
\text { Baik pelanggan maupun } \\
\text { operational staff perlu mengetahui } \\
\text { jadwal penggunakan lokasi event } \\
\text { untuk menghindari jadwal yang } \\
\text { berbenturan dengan jadwal } \\
\text { lainnya. }\end{array}$ & $\begin{array}{l}\text { Membuat website yang dapat } \\
\text { memperluas jangkauan pemasaran } \\
\text { Orchid Forest. } \\
\text { Sistem informasi yang dirancang } \\
\text { akan memudahkan pelanggan } \\
\text { dimanapun berada untuk dapat } \\
\text { melakukan reservasi dan } \\
\text { pembayaran. } \\
\text { Jadwal event yang sudah fix akan } \\
\text { tersimpan di database maka setiap } \\
\text { kali reservasi akan dilakukan, } \\
\text { sistem akan melakukan } \\
\text { pengecekkan untuk memastikan } \\
\text { apakah pada tanggal tersebut } \\
\text { jadwal telah tersedia atau tidak. } \\
\text { Hal ini untuk meminimalisir } \\
\text { jadwal yang berbenturan. }\end{array}$ & $\begin{array}{l}\text { Operational } \\
\text { staff }\end{array}$ \\
\hline 2 & $\begin{array}{l}\text { Pencatatan pembayaran dilakukan } \\
\text { pada sebuah buku. Hal ini rawan } \\
\text { akan kehilangan dan kerusakan. } \\
\text { Selain itu, akan membutuhkan } \\
\text { waktu yang relatif lama dalam } \\
\text { pengelolaannya, terutama saat } \\
\text { membuat laporan, }\end{array}$ & $\begin{array}{l}\text { Sistem informasi yang dirancang } \\
\text { akan mencatat data pembayaran } \\
\text { ke dalam database. Hal ini, akan } \\
\text { meminimalisir resiko kerusakan } \\
\text { dan kehilangan serta } \\
\text { mempermudah dalam penyusunan } \\
\text { laporan. }\end{array}$ & $\begin{array}{l}\text { Bagian } \\
\text { Keuangan }\end{array}$ \\
\hline
\end{tabular}

\subsection{Sistem yang diusulkan}

Berikut adalah prosedur sistem yang diusulkan: pelanggan dapat melihat informasi dan membuat reservasi acara melalui website. Proses reservasi di situs web akan membantu pelanggan menentukan tanggal reservasi acara. Jika tanggal tertentu telah dipesan oleh pelanggan lain, maka pelanggan tidak dapat memilih tanggal tersebut. Setelah melakukan 
pemesanan, pelanggan akan diberikan invoice. Pembayaran dapat dilakukan melalui transfer bank dan dikonfirmasi melalui website.

Gambar 2 menunjukkan use case dari desain layanan reservasi online. Aktor yang terlibat adalah pelanggan dan operational staff. Kedua aktor terhubung dengan promosi, pendaftaran, pemesanan, dan pembayaran. Pelanggan dapat melihat promosi di situs web. Namun, untuk dapat melakukan reservasi, pelanggan harus mendaftar terlebih dahulu. Setelah mendaftar, pelanggan dapat melakukan reservasi dan pembayaran melalui transfer bank yang dikonfirmasi melalui website.

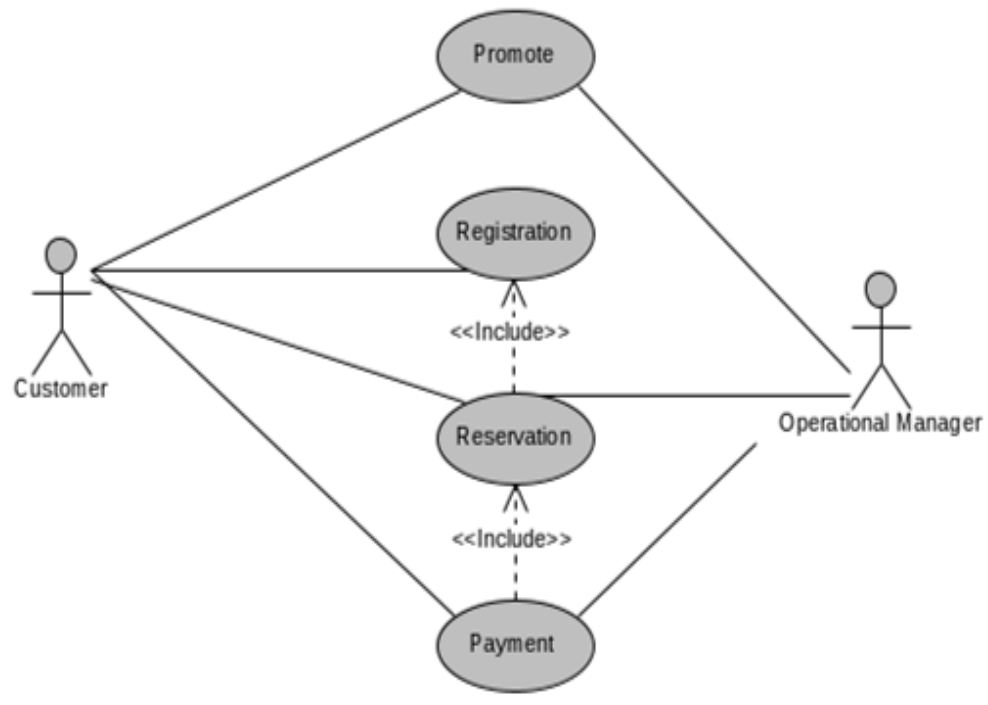

Gambar 2. Use case yang diusulkan

Operational staff dapat menambah dan memperbarui promosi di website. Operational staff juga dapat melihat pemesanan dan pembayaran pelanggan. Operational staff akan memeriksa pemesanan dan pembayaran pelanggan dan kemudian memvalidasinya.

Promosi dapat dilakukan operational staff dengan memperbaharui konten website, berisi foto-foto pemandangan Orchid Forest dan penawaran-penawaran mengenai reservasi event dan fasilitas serta layanan apa saja yang bisa didapatkan pelanggan di Orchid Forest.

Pelanggan harus melakukan registrasi terlebih dahulu sebelum dapat melakukan resevasi event. Registrasi dilakukan dengan mengisi data diri pelanggan seperti nama, alamat, termasuk e-mail dan nomor kontak. E-mail digunakan untuk mendapatkan notifikasi berkaitan dengan reservasi dan pembayaran yang dilakukan pelanggan. Setelah melakukan registrasi, pelanggan dapat login.

Reservasi event yang diusulkan dimulai dari pelanggan yang melakukan reservasi melalui sistem. Pelanggan dapat memilih paket event sesuai kebutuhannya pada daftar paket yang telah disediakan. Pelanggan akan mengisi data sesuai dengan kebutuhan event yang akan diselenggarakannya di Orchid Forest. Saat mengisi data tersebut, pelanggan akan dibantu dalam memilih lokasi event melalui jumlah kapasitas dari masing-masing tempat yang tersedia. Pelanggan juga perlu mengisi paket makanan yang akan dipilihnya. Masing-masing paket disertai keterangan menu makanan.

Setelah selesai mengisi form reservasi event, pelanggan akan mendapat besaran reservasi event yang harus dibayarkan. Pelanggan dapat menentukan apakah pembayaran akan dilunasi di awal atau membayar uang muka. Operational staff akan memeriksa reservasi yang dibuat oleh pelanggan untuk memastikan bahwa tanggal reservasi tidak bertentangan dengan acara yang dijadwalkan yang akan berlangsung. Setelah reservasi diverifikasi, pelanggan akan diminta untuk membayar biaya reservasi. 
Adapun aktivitas pembayaran yang dilakukan oleh pelanggan. Pelanggan yang telah melakukan pembayaran melalui transfer akan mengisi formulir konfirmasi pembayaran disertai dengan mengunggah bukti pembayaran. Operational staff akan memverifikasi tanda terima pembayaran yang diunggah oleh pelanggan. Setelah diverifikasi, pelanggan akan mendapatkan notifikasi dan pelanggan dapat mencetak bukti pembayaran terverifikasi sebagai bukti reservasi yang valid. Jika pembayaran yang dilakukan pelanggan adalah dengan uang muka, maka pelunasannya dapat dilakukan melalui transfer dan konfirmasi pembayaran melalui website atau dapat dilunasi langsung di kantor Orchid Forest.

Selain itu, penyimpanan data reservasi dan pembayaran dalam database akan memfasilitasi pelaporan dan meminimalkan kesalahan manusia, terutama dalam melaporkan dan memeriksa jadwal event untuk menghindari konflik jadwal event [10]. Ini berbeda dari penelitian sebelumnya yang berfokus pada mengelola pemesanan kamar dan booking ruang pelatihan [1][8].

Pada sistem yang dirancang terdapat pula fasilitas untuk mencetak laporan. Laporan yang dapat dihasilkan dari sistem, yaitu laporan reservasi event, laporan pembayaran, dan jadwal event. Operational staff hanya perlu menentukan periode laporan yang ingin ditampilkan.

\subsection{Antarmuka layanan reservasi online}

Adapun tampilan awal/home website yang dirancang seperti pada Gambar 3. Beberapa menu yang terdapat pada website, yaitu: home, login, daftar, tentang, daftar paket, fasilitas, reservasi, pembayaran, jadwal, dan profile.

Home merupakan tampilan awal dari website. Adapun menu tentang yang berisi hal-hal yang berkaitan dengan Orchid Forest. Pada menu daftar paket dan fasilitas, pelanggan dapat mengetahui daftar paket event apa saja yang terdapat di Orchid Forest serta fasilitas apa saja yang bisa didapatkan pelanggan. Pelanggan juga dapat melihat menu jadwal untuk mengetahui jadwal event yang akan diselenggarakan di Orchid Forest. Hal ini dapat membantu baik pelanggan maupun operational staff untuk menghindari jadwal event yang berbenturan.

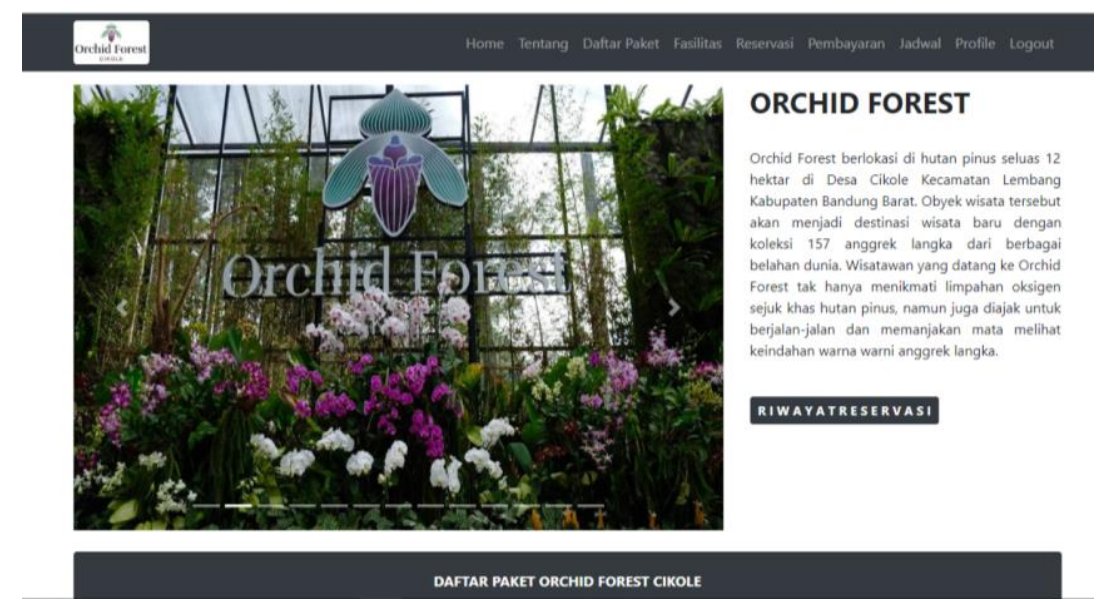

Gambar 3. Tampilan awal website

Pelanggan yang akan melakukan reservasi harus melakukan registrasi terlebih dahulu dengan memasukkan beberapa data diantaranya nama/institusi, no. telepon, alamat, $e$-mail, username, dan password. Klik tombol register untuk submit data yang telah diisi. Setelah registrasi berhasil, pelanggan dapat login untuk melakukan reservasi. Selain itu, dengan 
melakukan registrasi, pelanggan akan mendapatkan notifikasi ke $e$-mail mengenai reservasi event dan pembayaran.

Setelah login berhasil, pelanggan dapat melakukan reservasi dengan mengisi form space rent. Form ini berisi tanggal awal dan akhir pelangganan event, pemilihan lokasi event di Orchid Forest. Setelah memilih lokasi event, kapasitas dari lokasi tersebut akan muncul. Hal ini membantu pelanggan untuk menentukan lokasi yang sesuai dengan jumlah peserta atau undangan event yang akan digelarnya. Selain itu terdapat pula pemilihan paket event, paket makan, dan jenis pembayaran (uang muka atau lunas).

Selain melakukan reservasi, pelanggan juga dapat melakukan konfirmasi pembayaran reservasi melalui website dengan mengisikan data pembayaran, yaitu nomor reservasi, bank pengirim, bank tujuan, jumlah transer dan unggah bukti pembayaran. Jika pembayaran telah diverifikasi oleh operational staff, maka reservasi event dianggap sah. Pembayaran dengan uang muka, dapat dilunasi melalui konfirmasi di website atau pelunasan dilakukan langsung di kantor Orchid Forest.

Output yang dihasilkan oleh sistem berupa laporan reservasi dan laporan pembayaran dengan menentukan periode laporan yang akan dihasilkan.

\section{Kesimpulan}

Layanan reservasi online di Orchid Forest dapat membantu pelanggan untuk mendapatkan informasi yang memadai dan juga memudahkan mereka untuk dapat melakukan reservasi dan pembayaran melalui website. Dengan layanan reservasi online ini, pelanggan dapat mengetahui kapan waktu yang tepat untuk melakukan pemesanan. Sistem akan membantu pelanggan untuk mengetahui tanggal tertentu di mana pemesanan tidak dapat dilakukan. Selain itu, penyimpanan data pemesanan dan pembayaran dalam database serta memfasilitasi pelaporan.

\section{Daftar Pustaka}

[1] S. Osama, "Integrated Information System for Reserving Rooms in Hotels," (IJACSA) International Journal of Advanced Computer Science and Applications, Vol. 2, No. 10, pp. 48-52, 2011.

[2] K. Williams and A. Micheal, "Design and Implementation of Reservation Management System Case Study: Grand Ville Hotels," Journal of Information Technology \& Software Engineering, Vol. 8, No. 4, pp. 1-8, 2018.

[3] R. Akinyede et al, "Design and Implementation of an Booking System for a Cinema House," Journal of Information and Computing Science, Vol. 12, No. 2 pp. 113-122, 2017.

[4] M. F. Wicaksono dan I. K. Hamsir, "Sistem Informasi Reservasi Restoran," Jurnal Manajemen Informatika (JAMIKA), Vol. 9, No. 1, pp. 9-16, 2019.

[5] M. D. Rahmatya and M. F. Wicaksono, "Design of Student Attendance Information System with Fingerprints,” IOP Conf. Ser.: Mater. Sci. Eng. 662 022039, 2019.

[6] A. Bharadi et al, "e-Restaurant: Online Restaurant Management System for Android," IJACSA Special Issue on Selected Papers from International Conference \& Workshop on Advance Computing, pp. 48-54, 2013.

[7] E. S. Soegoto and R. Fadillah, "Design and Development of Ticket Reservation Information System in Travel Business," IOP Conf. Ser.: Mater. Sci. Eng. 407 012026, 2018.

[8] T. Wang and C. Bie, "Analysis and Design of Training Room Reservation Management System Based on SSH Framework," Journal of Physic: Conference Series 1288 012076, 2019. 
[9] H. M. Jogiyanto, “Analisis dan Desain Sistem Informasi”, Yogyakarta: Andi Offset, 2005.

[10] Yakub, "Pengantar Sistem Informasi", 1st ed, Yogyakarta: Graha Ilmu, 2012.

[11] Allen,J.,O'Toole, “Festival and Special Event Management, 2nd ed. Australia, 2002. Tersedia:

https://books.google.co.id/books/Special+Event+Management,2nd+ed.+Australia.ht $\underline{\mathrm{ml}}$.

[12] A. Saxena and P. Upadhyay, "Waterfall vs. Prototype: Comparative Study of SDLC," Imperial Journal of Interdiciplinary Research (IJIR), Vol. 2, Issue 6, pp. 1012-1015, 2016.

[13] H. Zhang, "Inapplicability, Redundancy and Uncertainty of UML," J. Phys.: Conf. Ser. 1168 062014, 2019. 